\title{
Utilization of non-protein nitrogen in the production of animal protein
}

\author{
By W. Chalupa, Applebrook Animal Health Research Center, Smith, Kline and \\ French Laboratories, 1600 Paoli Pike, West Chester, Pa. 19380, USA
}

Food production must continue to increase even if zero human population growth rates are achieved (Thompson, I972). The challenge is not only to produce additional quantities of staple food, but also to produce more and different types of protein-rich foods. One of the most serious of all world shortages is the supply of animal protein for human consumption. Plants and their products which constitute the major food supply in many countries often contain low concentrations of proteins and the protein may be deficient in one or more essential amino acids. In addition, man prefers to consume animal food products if they are available and if favourable economic conditions exist.

Because of their digestive capabilities, ruminant animals are, in terms of total resource utilization in the production of protein, an integral link in the human food chain. The biochemical, physiological, and practical aspects and consequences of utilization of non-protein nitrogen (NPN) in both ruminant and monogastric animals were reviewed recently (Chalupa, 1972; Kies, 1972; Lewis, 1972; Visek, 1972). The main emphasis in this report will be directed towards discussing the use of NPN for the production of animal protein.

\section{Protein nutrition of ruminant animals}

The protein nutrition of ruminant animals must be considered in terms of amino acids absorbed from the gastro-intestinal tract in relation to amino acids required for productive purposes. Amino acids available for absorption are supplied by microbial protein synthesized in the rumen, undegraded or protected food proteins and amino acids which bypass the rumen, and endogenous secretions. Probably little can be done to influence directly the amino acids provided by endogenous secretions. However, amino acids supplied by microbial protein and materials which bypass the rumen can be controlled. The desirable end result would logically appear to be maximization of rumen microbial-protein production from inexpensive NPN and supplementation of this microbial protein with amino acids or protein bypassing the rumen.

Rumen-protein production. Experiments reviewed by Purser (1970) and Chalupa (1972) indicated that rumen micro-organisms contain substantial amounts of nucleic acid $\mathrm{N}$ and the pattern of amino acids exhibits a remarkable consistency which does not appear to be influenced by diets. There are reports (Abdo, King 
\& Engle, 1964; Abou Akkada \& El-Shazly, 1965; Little, Mitchell \& Potter, 1965; Klopfenstein, Purser \& Tyznik, 1966) which indicate that the nutritive value of rumen microbial protein may vary, but manipulation of the quality of rumen microbial protein does not appear to be a major point of control in the production of edible protein in ruminant animals.

While recognizing that the quantity of cells formed in the anaerobic rumen fermentation system is a nutritional function of the supplies of energy, $N$, mineral elements and other required growth factors, only $\mathrm{N}$ and energy supplies will be discussed. Ammonia is not the only nitrogenous nutrient required for rumen microbial growth (Pilgrim, Gray, Weller \& Belling, I970; Al-Rabbat, Baldwin \& Weir, $1971 a, b$; but it is the main one (Bryant, 1963; Hungate, 1966; Allison, 1969; Chalupa, I972). It is, therefore, reasonable to assume that dietary NPN must be first transformed to ammonia which is subsequently utilized for microbial growth. Microbial enzymes controlling the rate and magnitude of ammonia production may be constitutive (i.e. urease) or may require the NPN source to be fed for a length of time to induce production for example of biuretase and uricase (Chalupa, 1972). NPN is used most efficiently for rumen-protein production when it produces an ammonia concentration in the rumen that is optimal for bacterial protein synthesis. When increasing amounts of urea were added to purified diets, Satter \& Slyter (1972), using continuous in vitro rumen fermentors, and Hume, Moir \& Somers (1970), working with sheep, found a linear increase in rumen microbial-protein outputs while ammonia concentrations remained low and constant up to a dietary crude-protein equivalent of about $110 \mathrm{~g} / \mathrm{kg}$. Diets with higher crude-protein contents produced no further increase in rumen-protein output, but ammonia concentrations increased. These reports demonstrate that rumen bacteria can scavenge ammonia from low concentration environments and that once ammonia starts to accumulate, the growth of ammonia-utilizing bacteria is not enhanced by providing additional urea. Satter \& Slyter (1972) found no detrimental effect on protein output resulting from high ammonia concentrations $(83 \circ \mathrm{mg} / \mathrm{l})$ but in vivo toxicities resulting from excessive ammonia production in the rumen are well-documented (Chalupa, I968, 1972). Both groups found that the currently accepted hypothesis of a close relationship between rumen microbial growth and fermentation activity (Hungate, Ig66) did not exist when ammonia was limiting.

Considerable attention has been focused on the quantitative relationship between rumen fermentation and microbial growth and it is recognized that cell yields in the anaerobic rumen fermentation are lower than in aerobic systems. A panel of experts (Anonymous, I972) recently concluded that $90-230 \mathrm{~g}$ microbial protein $/ \mathrm{kg}$ organic matter digested in the rumen could be produced. Quantities of ATP $/ \mathrm{mol}$ fermented carbohydrate or cell yields/mol ATP greater than anticipated would yield increased quantities of rumen microbial protein.

Because nutrients other than energy and $\mathrm{N}$ are needed for cell growth additional factors such as protein or peptide $\mathrm{N}$, carbon skeletons such as branched-chain volatile fatty acids, mineral elements or other growth factors may need to be supplied in the diet of ruminants given NPN to obtain maximum protein production in the 
rumen. In conclusion, the total quantity of protein produced in the rumen exhibits sufficient variation to indicate that it is a control point in the total protein economy of the animal which might be responsive to manipulation.

Supplementary amino acids and protein. Recognition of the quantitative limitations of rumen-protein production requires the provision of supplements of amino acids or proteins which bypass the rumen. It is known that not all dietary protein is degraded in the rumen, but the quantity which normally resists rumen degradation and bypasses the rumen does not appear to be sufficient to supplement rumenprotein production completely. In growing cattle given diets containing no NPN or only limited quantities we have consistently been able to double the quantity of $\mathrm{N}$ retained by infusing casein, casein hydrolysate or a mixture of ten essential amino acids into the abomasum (Chalupa, Chandler \& Brown, 1972). When NPN is fed, less dietary protein is available for rumen bypass and, therefore, greater quantities of protected amino acids or proteins may be needed. The greatest need for supplemental amino acids occurs when the requirement is for a high level of amino acids in relation to energy requirements and supply. Cattle and sheep during growth and early fattening periods, mature sheep maintained on low-energy diets and utilized for wool production and lactating dairy cattle should theoretically require the greatest quantities of supplemental amino acids. Additional published information on amino acid nutrition of ruminants is readily available (Nelson, I970; Purser, 1970; Chalupa, 1972; Chalupa \& Chandler, 1972).

Whether to provide for rumen bypass of single amino acids, mixtures of amino acids or entire proteins will depend upon whether shortages of a few or many amino acids are limiting production. It is important to recognize that treatment procedures which prevent rumen degradation must not interfere with digestive release of amino acids in the abomasum and small intestine.

\section{NPN as a component of ruminant diets}

NPN can be used in the feeding of ruminant animals but the final decision to feed NPN should be governed by the practical conditions prevailing in specific situations and is influenced by economic conditions.

Practical considerations. Successful practical use takes advantage of the known biochemical and physiological aspects of NPN utilization both in the rumen and in the host animal. Good animal management is required.

Perhaps the most important consideration in identifying a situation in which NPN would be beneficial and establishing the amounts of NPN to use is the nature of the basal diet, especially the types and concentration of both the $\mathrm{N}$ and energyyielding components. As discussed earlier, little benefit can be expected from NPN if the dietary ingredients are already yielding a rumen-ammonia pool of sufficient magnitude to meet the requirements of ammonia-utilizing rumen microbes or if the dietary ingredients do not supply sufficient energy for microbial growth. The ratio between rumen-ammonia production and energy production, which is governed by the dietary ingredients fed, is, therefore, the primary factor responsible for the degree of effectiveness of NPN supplementation. The addition of urea to increase 
purified dietary crude-protein contents above about I $10 \mathrm{~g} / \mathrm{kg}$ did not further increase rumen-protein production (Hume et al. 1970; Satter \& Slyter, 1972). NPN can be used to increase natural dietary crude-protein contents to a higher level (i.e. perhaps I $40 \mathrm{~g} / \mathrm{kg}$ ) because some dietary protein normally escapes rumen degradation and does not contribute to the rumen-ammonia pool. A method of assessing the quantity of NPN which might be utilized with a particular diet would be to monitor rumenammonia concentrations in relation to NPN additions since the point of rumenammonia accumulation signifies the point of maximum rumen-protein output.

Burroughs, Trenkle \& Vetter ( $197^{2}$ ) have proposed a system of identifying dietary situations which will benefit from NPN (specifically urea) supplementation. The contribution of dietary ingredients to the rumen-ammonia pool is considered in relation to the energy provided by the ingredient for rumen microbial growth. While there is insufficient quantitative information to substantiate many of their feed values, their categorization of feed ingredients as to suitability for use with urea is interesting.

Economic considerations. Because of the problems associated with feeding NPN it is doubtful whether NPN would be used as a component of ruminant diets unless feed protein sources were limited in supply and/or the cost was in favour of NPN. Both situations are currently being encountered in the USA; the price of soya-bean meal, for example, is two to three times greater than a year ago and purchase, even at the exaggerated price, is difficult due to limited supplies. This has resulted in increased demands for NPN, especially dry urea and urea-containing liquid supplements. In many areas of the world the current US situation has occurred and will continue.

Examples of successful NPN utilization. The current use in livestock feeds of 800000 tons urea/year in the USA suggests that NPN can be utilized effectively in situations of high rates of animal productivity, and, while productivity increases resulting from adding NPN to the basal diet may not be large, they are of economic significance. NPN is used mainly as a replacement for oilseed meals and is most commonly added to concentrate mixtures, to complete feeds, to molasses-based liquid supplements, or to maize silage either at ensiling or at feeding (Chalupa, 1970a). Usually the basal rations supplemented with NPN are not especially low in protein and may already supply approximately seventy per cent of the animal's total protein requirement. Positive benefits are obtained primarily because rations are high in energy content and are fed $a d l i b$. As discussed earlier, feed ingredients to be used as components of NPN-supplemented diets must be selected with care and there are probably instances where use of NPN is not effective.

Grains are available for livestock feeding only when their production exceeds the quantity needed for human consumption. The absence of indigenous grain production has hindered the development of a viable livestock industry in many areas. Molasses, obtained as a by-product from the sugar cane industry, provides many tropical countries with a mechanism to develop an intensive animal agriculture in the absence of available feed grains (Chicco, Shultz, Shultz, Carnevali \& Ammerman, 1972; Preston, I972a,b). The beef-cattle fattening plan developed 
by Preston (1972a,b) for Cuba uses molasses as an energy source, urea to supply the rumen microbes with necessary ammonia and fish meal to bypass the rumen and compensate for the limitations of rumen-protein production.

Use of NPN with high-fibrous, low-energy feed materials cannot be ignored. Sixty-four per cent of the world's agricultural land is suitable only for forage production. In addition, crop and industrial by-products are a large reservoir of plant carbon which can be converted into animal $\mathrm{C}$ by ruminants. Compatibility of NPN with such feed ingredients may necessitate treatment(s) to increase availability of rumen energy or may involve the use of NPN compounds which give patterns of ammonia-release different from that of urea. Oltjen, Williams, Slyter \& Richardson (1969) demonstrated that respectable animal performance could be obtained in fattening beef cattle fed forage-based NPN diets. Timothy-hay diets supplemented with urea and biuret yielded daily gains of $0.8 \mathrm{I}$ and $0.74 \mathrm{~kg}$ when fed ad lib. Biuret was clearly the superior NPN source when diets were fed twice daily.

Low-protein forages often available to grazing ruminants are usually consumed in inadequate amounts and deficiencies of both protein and energy are encountered. In these situations, reduction of weight losses and future productivity of the animals rather than positive weight gains may be the primary objective. Ammerman, Verde, Moore, Burns \& Chicco (1972) and Fick, Ammerman, McGowan, Loggins \& Conell (1973) reported that urea, biuret or natural protein supplementation increased intakes of low-quality forages and improved $\mathrm{N}$ retention in sheep. Thomas (1972) demonstrated that NPN, especially biuret, is an effective $\mathrm{N}$ supplement for cattle on range during the winter months. The use of NPN supplements in Africa was recently reviewed by Topps (1972).

The use of NPN sources other than urea as components of ruminant diets has been reviewed (Chalupa, I970b). Unfortunately, most alternative NPN sources have not been adequately researched in animal trials.

\section{Role of ruminants as producers of protein}

Kroeske (1972) suggested narrowing the animal-protein gap with swine and poultry rather than with ruminants because ruminants have a low prolificacy rate and high generation interval so that it takes longer to increase ruminant numbers and improve their genetic potential.

Low genetic potential is no doubt a problem, but there may well be sufficient numbers of ruminant animals available. Seventy per cent of the world's cattle and buffalo population is found in developing countries, but they yield only twentyone per cent of the world's milk and thirty-four per cent of the beef produced (Jasiorowski, 1972). Much of this livestock pool suffers from malnutrition and disease which renders them completely unproductive or they produce at such low levels that their contribution to man's welfare is negligible or may even be negative. Not all of this livestock pool is available for food production, but improved disease control and nutrition could increase the quantity of animal protein produced from ruminants. Ruminant animals are important suppliers of animal protein in terms of total resource utilization even if NPN is not fed, because they can be fed forages 
and other nutrient sources inedible by man or only limited amounts of cereal grains. Moore, Putnam \& Bayley ( 1967 ) used input-output results from a survey on 1500 cows and calculated that ninety-six per cent of the protein in cereals and oilseed meals consumed by these cows was returned as milk protein. If the ruminant's capacity to utilize NPN is considered, their role in the production of animal protein is even stronger (Chalupa, 1972).

The potential for animal-protein production from NPN was demonstrated in experiments of Virtanen ( 1966 ) and Oltjen ( 1969 ). Growth, reproduction and lactation were obtained on protein-free diets containing more than ninety-seven per cent of the $\mathrm{N}$ from NPN. Animal productivity was lower than is considered desirable, but lesser reductions result when a smaller quantity of NPN is used. In some instances, lowered rates of animal productivity which might result from feeding NPN may be offset by the economics and availability of NPN compared with plant protein.

\section{Conclusions}

The metabolic machinery of ruminant animals, like that of other living organisms, must be supplied with the proper types and amounts of amino acids. Utilization of NPN for rumen-protein production and supplementation with amino acids or protein bypassing the rumen is the logical approach to production of animal protein with ruminants. Contribution of ration ingredients to the rumen-ammonia pool in relation to energy provided by the ingredients for microbial growth is the main factor governing the magnitude of responses obtained by adding NPN to ruminant diets. NPN is used most effectively in low-protein, high-energy diets, but benefits have been obtained when NPN was added to cereal grain-based diets containing moderate quantities of protein and with low-energy, fibrous diets. Ruminant animals are important producers of protein in developed countries and have advantages in developing areas.

\section{REFERENCES}

Abdo, K. M., King, K. W. \& Engle, R. W. (1964). F. Anim. Sci. 23, 734.

Abou Akkada, A. R. \& El-Shazly, K. (1965). F. agric. Sci., Camb. 64, 25 I.

Allison, M. J. (I969). F. Anim. Sci. 29, 797.

Al-Rabbat, M. F., Baldwin, R. L. \& Weir, W. C. (1971a). F. Dairy Sci. 54, 1 150.

Al-Rabbat, M. F., Baldwin, R. L. \& Weir, W. C. (1971b). F. Dairy Sci. 54, I I 5 o.

Ammerman, C. B., Verde, G. J., Moore, J. E., Burns, W. C. \& Chicco, C. F. (1972). F. Anim. Sci. 35, 121 .

Anonymous (1972). In Tracer Studies on Non-protein Nitrogen for Ruminants p. 171. Vienna: International Atomic Energy Agency.

Burroughs, W., Trenkle, A. H. \& Vetter, R. L. (1972). Iowa State University Animal Science Leaflet $R \mathrm{I} 6 \mathrm{I}$.

Bryant, M. P. (1963). F. Anim. Sci. 22, 801 .

Chalupa, W. (I968). F. Anim. Sci. 27, 207.

Chalupa, W. (1970a). Proc. Cornell Nutr. Conf. p. 64.

Chalupa, W. (1970b). Clemson Univ. Dairy Sci. Res. Ser. no. 54.

Chalupa, W. (1972). Fedn Proc. Fedn Am. Socs exp. Biol. 31, r 152.

Chalupa, W. \& Chandler, J. E. (1972). In Tracer Studies on Non-Protein Nitrogen for Ruminants p. 107. Vienna: International Atomic Energy Agency.

Chalupa, W., Chandler, J. E. \& Brown, R. E. (1972). Fedn Proc. Fedn Am. Socs exp. Biol. 31, 681. 
Chicco, C. F., Shultz, T. A., Shultz, E., Carnevali, A. A. \& Ammerman, C. B. (1972). F. Anim. Sci. 35,859 .

Fick, K. R., Ammerman, C. B., McGowan, C. H., Loggins, P. E. \& Conell, J. A. (1973). F. Anim. Sci. 36, 137 .

Hume, I. D., Moir, R. J. \& Somers, M. (1970). Aust. F. agric. Res. 21, 283.

Hungate, R. E. (I966). The Rumen and Its Microbes. New York: Academic Press.

Jasiorowski, H. A. (1972). Wld Anim. Rev. 1, 2.

Kies, C. (1972). Fedn Proc. Fedn Am. Socs. exp. Biol. 31, I I72.

Klopfenstein, T. J., Putser, D. B. \& Tyznik, W. J. (1966). F. Anim. Sci. 25, 765.

Kroeske, D. (1972). Wld Anim. Rev. 2, 15.

Lewis, D. (1972). Fedn Proc. Fedn Am. Socs exp. Biol. 31, I $65 ._{5}$

Little, C. O., Mitchell, G. E. \& Potter, G. D. (1965). F. Anim. Sci. 24, 893.

Moore, L. A., Putnam, P. A. \& Bayley, N. D. (ig67). Agric. Sci. Res. 5, I.

Nelson, L. F. (1970). Proc. Am. Feed Mfrs Ass. Nutr. Coun., 13.

Oltjen, R. R. (1969). F. Anim. Sci. 28,673.

Oltjen, R. R., Williams, E. E., Slyter, L. L. \& Richardson, G. V. (1969). J. Anim. Sci. 29, 816.

Pilgrim, A. F., Gray, F. V., Weller, R. A. \& Belling, C. B. (I970). Br. F. Nutr. $24,589$.

Preston, T. R. (1972a). In Tracer Studies on Non-protein Nitrogen for Ruminants p. I. Vienna: International Atomic Energy Agency.

Preston, T. R. (1972b). Wld Anim. Rev. I, 24.

Purser, D. B. (1970). F. Anim. Sci. 30, 988 .

Satter, L. D. \& Slyter, L. L. (1972). F. Anim. Sci. 35, 273.

Thomas, O. O. (1972). Proc. 23 rd Annual Montana Nutr. Conf. Bozeman, Montana, USA.

Thompson, L. M. (1972). Proc. Iowa State University Nutr. Symp. on Proteins. Ames, Iowa: Iowa State University Press.

Topps, J. H. (1972). Wld Anim. Rev. 3, 14.

Virtanen, A. I. (1966). Science, N.Y. 153, 1603 .

Visek, W. J. (1972). Fedn Proc. Fedn Am. Socs exp. Biol. 31, 1178. 